This item was submitted to Loughborough's Research Repository by the author.

Items in Figshare are protected by copyright, with all rights reserved, unless otherwise indicated.

\title{
The relationship of early-life adversity with adulthood weight and cardiometabolic health status in the 1946 National Survey of Health and Development
}

\section{PLEASE CITE THE PUBLISHED VERSION}

http://doi.org/10.1097/PSY.0000000000000751

\section{PUBLISHER}

Lippincott, Williams \& Wilkins

\section{VERSION}

AM (Accepted Manuscript)

\section{PUBLISHER STATEMENT}

This is a non-final version of an article published in final form in Robson, E. ... et al., 2020. The Relationship of Early-Life Adversity With Adulthood Weight and Cardiometabolic Health Status in the 1946 National Survey of Health and Development. Psychosomatic Medicine. 82(1):82-89.

\section{LICENCE}

CC BY-NC-ND 4.0

\section{REPOSITORY RECORD}

Robson, Ellie, Tom Norris, W Wulaningsih, Mark Hamer, Rebecca Hardy, and William Johnson. 2019. "The Relationship of Early-life Adversity with Adulthood Weight and Cardiometabolic Health Status in the 1946 National Survey of Health and Development". figshare. https://hdl.handle.net/2134/9885623.v1. 
The relationship of early-life adversity with adulthood weight and cardiometabolic health status in the 1946 National Survey of Health and Development

Ellie Robson BSc${ }^{1}$, Tom Norris $\mathrm{PhD}^{1}$, Wahyu Wulaningsih $\mathrm{PhD}^{2}$, Mark Hamer $\mathrm{PhD}^{1}$, Rebecca Hardy $\mathrm{PhD}^{34}$, William Johnson $\mathrm{PhD}^{1}$

${ }^{1}$ School of Sport, Exercise and Health Sciences, Loughborough University, Loughborough ${ }^{2}$ Deaneary of Molecular, Genetic, and Population Health Sciences, Edinburg Research Explorer, The University of Edinburgh ${ }^{3} \mathrm{MRC}$ Unit for Lifelong Health and Ageing at UCL ${ }^{4}$ CLOSER, UCL Institute of Education, London

\section{Correspondence}

William Johnson

w.o.johnson@lboro.ac.uk

School of Sport, Exercise, and Health Sciences, Loughborough University, Loughborough, Leicestershire, UK, LE11 3TU

01509228057

\section{Word: 5569}

Tables: 6

\section{Conflicts of Interest and Source of Funding}

$\mathrm{RH}$ is Director of the CLOSER consortium which is supported by funding from the Economic and Social Research Council (ESRC) and the Medical Research Council (MRC). An initial grant for this work was awarded to CLOSER in 2012 and extended, by the ESRC, in 2017 (award reference: ES/K000357/1). RH was supported by the UK Medical Research Council (Programme code: MC_UU_12019/2). The UK Medical Research Council provides core funding for the MRC National Survey of Health and Development.

WJ is supported by a UK Medical Research Council (MRC) New Investigator Research Grant (MR/P023347/1). WJ \& MH acknowledge support from the National Institute for Health Research (NIHR) Leicester Biomedical Research Centre, which is a partnership between University Hospitals of Leicester NHS Trust, Loughborough University, and the University of Leicester. 
This work was supported by a UK Medical Research Council (MRC) New Investigator Research Grant (MR/P023347/1).

All authors declare no conflicts of interest. 


\section{SUMMARY}

Childhood adversity might cause obesity via the adoption of unhealthy behaviours. It might also cause poor cardiometabolic health, either via obesity or another pathway (e.g., altered stress response). Robson et al found that childhood adversity was associated with poor cardiometabolic health at ages 60-64 years, in both normal weight and overweight/obese adults. Further research is needed to understand the mechanisms by which childhood adversity might affect cardiometabolic health without necessarily increasing body weight. 


\section{ABSTRACT}

\section{Objectives}

Evidence linking early-life adversity with an adverse cardiometabolic profile in adulthood is equivocal. This study investigates early-life adversity in relation to weight and cardiometabolic health status at age 60-64 years.

\section{Methods}

We included 1,059 individuals from the 1946 National Survey of Health and Development (NSHD). Data on adversity between ages 0-15 years were used to create a cumulative childhood psychosocial adversity score and a socioeconomic adversity score.

Cardiometabolic and weight/height data collected at ages 60-64 years were used to create four groups: metabolically healthy normal weight (MHNW), metabolically unhealthy normal weight (MUNW), metabolically healthy overweight/obese (MHO), and metabolically unhealthy overweight/obese (MUO). Associations between the two exposure scores and weight/health status were examined using multinomial logistic regression, with adjustment for sex and age at the outcome visit.

\section{Results}

$62 \%$ of normal weight individuals were metabolically healthy, whereas only $34 \%$ of overweight/obese individuals were metabolically healthy. In a mutually adjusted model including both exposure scores, a psychosocial score of $\geq 3$ (compared to 0 ) was associated with increased risk of being metabolically unhealthy (compared to healthy) in both normal weight adults (RR 2.49; 95\% Cl 0.87, 7.13) and overweight/obese adults $(1.87 ; 0.96,3.61)$. However, the socioeconomic adversity score was more strongly related to metabolic health status in overweight/obese adults $(1.60 ; 0.98,2.60)$ than normal weight adults $(0.95 ; 0.46$, 1.96). 


\section{Conclusions}

Independently of socioeconomic adversity, psychosocial adversity in childhood may be associated with a poor cardiometabolic health profile, in both normal weight and overweight/obese adults.

\section{Key words}

Childhood adversity, socioeconomic adversity, cardiometabolic profile, weight status, cohort study

Adverse childhood events (ACEs)

Avon Longitudinal Study of Parents and Children (ALSPAC)

Body mass index (BMI)

Glycosylated haemoglobin ( $\mathrm{HbA} 1 \mathrm{c})$

High-density lipoprotein-cholesterol (HDL-C)

Metabolically healthy normal weight (MHNW)

Metabolically healthy obesity (MHO)

Metabolically unhealthy normal weight (MUNW)

Metabolically unhealthy obesity (MUO)

National Survey for Health and Development (NSHD)

Percentage body fat (\%fat) 


\section{INTRODUCTION}

Obesity is a major public health concern, in part because it increases risk of cardiometabolic complications such as cardiovascular disease and type two diabetes.[1] Not all obese individuals, however, develop such conditions and there is heterogeneity in cardiometabolic health among individuals with obesity, and indeed within any weight status group.[2, 3] Categorising people based on their weight and health status is a common way to capture this heterogeneity. A lot of research has focused on the group with "so-called" metabolically healthy obesity (MHO), which is most commonly defined as obesity in the presence of fewer than two metabolic abnormalities, normally including dyslipidaemia, hypertension, and diabetes.[4]

Most of the existing literature on $\mathrm{MHO}$ has investigated its relationship with risk for future disease outcomes or death.[5, 6] While MHO is certainly not a benign condition, metaanalysed risks of outcomes like cardiovascular disease and type two diabetes are lower in this group compared against individuals with metabolically unhealthy obesity (MUO).[2, 3] Very few studies, however, have investigated which early-life risk factors might explain such heterogeneity in health prospects among individuals with obesity.[5, 6] The strongest evidence suggests that greater severity and duration of exposure to obesity is related to increased risk of MUO compared to $\mathrm{MHO}$, but evidence on modifiable or targetable early-life risk factors is lacking.[7-9] Understanding what contributes to the risk of developing a metabolically unhealthy profile in different weight categories is important as it could inform prevention and intervention programmes to delay the onset of cardiometabolic complications, even among those individuals who are obese. While an exposure of interest (e.g., smoking) might be related to increased risk of MUO compared to $\mathrm{MHO}$, it might not necessarily be related to health status among normal weight individuals. Such effect modification by weight status is equally as important to understand for prevention and 
intervention programmes and might implicate obesity as part of the exposure-disease mechanism.

Previous studies have reported measures of psychosocial stress, such as adverse childhood events (ACEs) (e.g., abuse, neglect, and parental divorce) and socioeconomic adversities (e.g., low head of household social class, low income, household overcrowding, and low parental education), to be associated with increased risk of diseases like cardiovascular disease and type two diabetes.[10-13] The association of childhood adversity with a subclinical cardiometabolic profile appears, however, to be equivocal. Previous analyses in two birth cohort studies in the UK found no consistent evidence that childhood adversity is related to continuous measures of cardiometabolic disease risk.[14, 15] In a study in Dunedin, New Zealand, however, Danese et al found an association between greater cumulative childhood adversity and increased risk for cardiometabolic marker clustering at age 32 years in a sample of 1,037 normal weight, overweight, and obese individuals.[16] To our knowledge, this finding has not been further examined at a later age in adulthood and separately within different weight status groups.

Using data from the Medical Research Council 1946 National Survey for Health and Development (NSHD), this study investigates the relationships of early-life psychosocial and socioeconomic adversity with weight and cardiometabolic health status at age 60-64 years. We hypothesise that greater adversity will be associated with increased risk of MUO compared to MHO, and also of metabolically unhealthy normal weight (MUNW) compared to metabolically healthy normal weight (MHNW).

\section{METHODS}

\section{Study Sample}


The NSHD is an on-going study. The cohort initially consisted of 5,362 singleton births that occurred during one week in March 1946 in England, Wales, and Scotland.[17] Between 2006-2011, eligible participants (those known to be alive and living with an address in either England, Scotland, or Wales) were invited to attend a clinical assessment at one of six clinical research facilities or by a research nurse at home. A total 2,229 participants out of the 2856 invited (78\%) underwent assessment: 1690 attended a clinical research facility and the remaining 539 were seen in their homes.[18] Invitations were not sent to those who had died $(N=778)$, who were living abroad $(N=570)$, had previously withdrawn from the study ( $N=594)$, or had been lost to follow-up $(N=564)$. The study obtained ethical approval from Greater Manchester Local Research Ethics Committee and the Scotland Research Ethics committee.

To be included in the present study participants had to have available data on childhood adversity and body mass index (BMI) and cardiometabolic data at ages 60-64 years. Participants classified with BMI $\leq 18.5 \mathrm{~kg} / \mathrm{m}^{2}$ were also excluded. Of the 2,229 eligible individuals, 1,059 individuals met these criteria. Briefly, of the 2,229 assessed at ages 60-64 years, three did not have age at outcome assessment, 13 had a BMI $\leq 18.5 \mathrm{~kg} / \mathrm{m}^{2}$, an additional 348 did not have the data to define weight/health status, an additional 349 did not have the data to define childhood SEP adversity, and an additional 457 did not have the data to define childhood psychosocial adversity. Supplementary Table 1 presents differences between the sample $(N=1,059)$ and individuals excluded from analyses due to missing data $(\mathrm{N}=2,229-1,059=1170)$.

\section{Exposures}

Data on psychosocial and socioeconomic adversities between zero and 15 years of age were used. The majority of data were assessed by maternal or guardian report, augmented by health visitor and teacher reports. Psychosocial adversities included the following: maltreatment (retrospectively assessed at age 43 years), low parental concern for child's 
education, parental psychiatric history, parental divorce, mother affectionless control (retrospectively assessed at age 43 years), father affectionless control (retrospectively assessed at age 43 years), parental death, maternal separation. Socioeconomic adversities included: low maternal education, low father social class, renting a house from a private landlord, poor household amenities, overcrowding, poorly repaired house, unclean child, poorly cleaned house, poor state of child's clothes and shoes. Supplementary Table 2 provides a more detailed description of these variables. For each individual psychosocial or socioeconomic adversity, the variable was coded as 0 (no adversity) or 1 (presence of adversity). These numbers were then summed together to create two exposures: a composite psychosocial adversity score and a composite socioeconomic adversity score, each of which was further categorised as $0,1,2$, or $\geq 3$ adversities. These scores were created in order to capture repeated exposure to stressful events, as has been previously used by Caleytchetty et al.[19]

\section{Outcomes}

At ages 60-64 years, weight $(\mathrm{kg})$ and height $(\mathrm{m})$ were measured. Diastolic and systolic blood pressures $(\mathrm{mmHg})$ were assessed and a fasting blood sample was taken to assay glycosylated haemoglobin $(\mathrm{HbA} 1 \mathrm{c})$, high-density lipoprotein-cholesterol (HDL-C) (mmol/L), and triglycerides (mmol/L). Use of antihypertensives, antidiabetics, lipid-lowering drugs, and insulin was self-reported. Detailed description of he methods used to collected these data is provided by Kuh et al.[18]

Overweight or obesity was defined as a BMI $\geq 25 \mathrm{~kg} / \mathrm{m}^{2}$; these groups were combined for sample size reasons. Individuals were classified as being metabolically unhealthy if they had two or more of the following complications: 1) impaired glucose metabolism, defined as $\mathrm{HbA} 1 \mathrm{C} \geq 5.7 \%$, or use of antidiabetic drugs or insulin;[20] 2) elevated blood pressure, defined as systolic blood pressure $\geq 130 \mathrm{mmHg}$ and diastolic blood pressure $\geq 85$ $\mathrm{mmHg},[21]$ or use of antihypertensive medications; 3) low HDL-C, based on a cut-off of 1.03 
$\mathrm{mmol} / \mathrm{L}$ in men and $1.29 \mathrm{mmol} / \mathrm{L}$ in women;[21] 4) hypertriglyceridemia, defined as triglyceride level $\geq 1.70 \mathrm{mmol} / \mathrm{L},[21]$ or use of lipid-lowering drugs, the majority of which are known to reduce triglycerides levels by $50-60 \%$.[22]

Individuals were categorised as either MHO, MUO, MHNW, or MUNW.

\section{Covariates}

Age in months at the 60-64 years of age assessment was recorded, as was sex at birth.

\section{Statistical analysis}

Differences between the four weight/health status groups were examined using chi-square for categorical variables and ANOVA for continuous variables (log transformed if not normally distributed). The psychosocial adversity score and socioeconomic adversity score were tabulated and their relationship tested using chi-square.

Firstly, separate associations of the psychosocial adversity score and the socioeconomic adversity score with both a binary health status outcome (unhealthy vs healthy) and a binary weight status outcome (overweight/obese vs normal weight) were examined using logistic regression, with adjustment for age and sex. Secondly, associations of the psychosocial adversity score and the socioeconomic adversity score with the composite weight/health status outcome were examined using multinomial logistic regression, with adjustment for age and sex. Each adversity score was examined separately, before putting them together in a mutually adjusted model. Post-estimation commands were used to obtain the relative risks of MUO compared to MHO and of MUNW compared to MHNW. P-values for trends (i.e., linear effect across all categories of an exposure) were obtained by entering the exposures into the models as continuous variables. 
In order to test whether our results were biased by complete case analysis, we re-ran the final mutually adjusted model on five multiply imputed datasets. We imputed back up to the 1,865 individuals who were missing data on the exposures but not the outcome. Briefly, we used chained equations to impute the two adversity scores based on 10 individual adversities (with no or minimal missing data), age, sex, weight/health status and all of its components (e.g., systolic blood pressure and HDL-C), and an overall social class variable from ages 26,36 , and 43 years. The analytical model was applied to the multiple-imputed data, using Rubin's rules to combine estimates across the five datasets.

Because BMI is a limited indictor of adiposity,[23] a sensitivity analysis was conducted in which weight status was defined according to percentage body fat (\%fat) assessed by a Hologic (Bedford, MA, USA) QDR 4,500 dual-energy x-ray absorptiometry scanner, as previously described.[18] Of the 1,059 individuals in the analysis sample, 783 individuals had available DXA data. Using NHANES 1999-2004 cut-offs, overweight or obesity was defined as $\%$ fat $\geq 39.99 \%$ for females and $\geq 19.00 \%$ for males.[24]

All analyses were carried out using Stata MP version 14 (StataCorp LP, College Station, TX, USA).

\section{RESULTS}

Table 1 shows descriptive statistics, by weight/health status. $62 \%$ of the 312 normal weight individuals were metabolically healthy, whereas only $34 \%$ of the 747 overweight or obese individuals were metabolically healthy. The MUO group contained approximately twice the percentage of people with $\geq 3$ adversities (psychosocial or socioeconomic) compared to the MHO group. Supplementary Table 3 shows the prevalence of individual adversities by weight/health status. 
The psychosocial adversity score and the socioeconomic adversity score demonstrated a positive relationship, with a chi-square test reporting $p=0.017$ (Table 2).

Table 3 shows the relationship of each adversity score with health status (unhealthy vs healthy) and weight status (overweight/obese vs normal weight) considered separately. While the psychosocial adversity score and the socioeconomic adversity score were both related to increased risk of being unhealthy, only the socioeconomic adversity score was related to increased risk of being overweight/obese.

Multinomial logistic regression analyses for each exposure considered separately demonstrated associations of the psychosocial adversity score and the socioeconomic adversity score with increased risk of MUO compared to MHO (Table 4). For example, individuals with a psychosocial adversity score of $\geq 3$ (compared to 0$)$ had a $2.01(95 \% \mathrm{Cl}$ 1.04, 3.88) times higher risk of MUO than MHO. Similarly, individuals with a socioeconomic adversity score of $\geq 3$ (compared to 0 ) had a $1.65(1.01,2.67)$ times higher risk of MUO than $\mathrm{MHO}$. Among normal weight individuals, however, only psychosocial adversity was related to increased risk of being metabolically unhealthy.

In a mutually adjusted model, estimates were only slightly attenuated (Table 5). Individuals with a psychosocial adversity score of $\geq 3$ (compared to 0 ) had a $1.87(0.96,3.61)$ times higher risk of MUO than $\mathrm{MHO}$; individuals with a socioeconomic adversity score of $\geq 3$ (compared to 0 ) had a $1.60(0.98,2.60)$ times higher risk of MUO than MHO; and again only psychosocial adversity was related to increased risk of being metabolically unhealthy among normal weight individuals. Further, the $p$-values for trends provided evidence that increasing psychosocial adversity had a linear relationship with greater risk of MUNW (compared to MHNW) and that increasing socioeconomic adversity had a linear relationship with greater risk of $\mathrm{MUO}$ (compared to $\mathrm{MHO}$ ). Similar results were obtained using multiple imputation to increase the sample size (Supplementary Table 4). 
When outcome groups were defined using \%fat, the associations for psychosocial adversity score were generally of a similar magnitude but with slightly wider confidence intervals (Table 6). The relationship of a socioeconomic adversity score of $\geq 3$ with MUO (compared to $\mathrm{MHO}$ ) was, however, attenuated more drastically from a $60 \%$ increased risk to only a $22 \%$ increased risk when weight status was defined according to \%fat.

\section{DISCUSSION}

This study found that, independently of socioeconomic adversity, children exposed to the highest level of psychosocial adversity had increased risk of being metabolically unhealthy at ages 60-64 years in both normal weight and overweight/obese groups. Conversely, however, the highest level of socioeconomic adversity was only associated with increased risk of being metabolically unhealthy in the overweight/obese group.

Socioeconomic adversity and ACEs are known to be related to increased risk of diseases like cardiovascular disease, cancer, respiratory disease, and type two diabetes.[7, 10, 12, $25,26]$ The associations of these exposures with sub-clinical outcomes such as an adverse cardiometabolic profile are equivocal and necessary to investigate further, in order to better understand the potential mechanisms.[14, 15, 27, 28] Also using data from the NSHD, and a nearly identical psychosocial adversity score $(0,1,2$, or $3+)$, Anderson et al did not find consistent evidence of any relationship with mean-levels of continuous cardiometabolic disease risk marker outcomes (e.g., blood pressures, cholesterols, triglycerides, glucose, insulin, c-reactive protein, carotid intima media thickness, and pulse wave velocity).[14] Similarly, Anderson et al found no evidence of associations in a sample of females aged 51 years at follow-up in the Avon Longitudinal Study of Parents and Children (ALSPAC).[15] The results of these two studies may have been null for a number of reasons, one being that adversity may have greater effect at higher parts of a risk factor distribution than at the mean 
(e.g., adversity might be related to higher systolic blood pressure among a sub-group of individuals who are hypertensive, while having no or minimal effect on the mean in the full sample). By using a composite cardiometabolic health outcome, which identifies individuals with multiple risk factors, we were able to reveal some of the possible long-term consequences of early-life adversity. This finding is in agreement with the Danese et al study, which founds relationships between socioeconomic adversity and social isolation with composite cardiometabolic health status at age 32 years in a sample of 1,037 normal weight, overweight, and obese individuals in Dunedin, New Zealand.[16]

Multiple mechanisms may explain the associations observed in the present study. The relationship between both adversity scores and poor cardiometabolic health status in the overweight/obese group could operate via greater life-time exposure to BMI (e.g., earlieronset of overweight/obesity), because socioeconomic adversity and ACEs are related to unhealthier BMI trajectories.[29, 30] Similarly, socioeconomic adversity and ACEs are both related to the adoption of unhealthy lifestyle behaviours, which could partly mediate the associations we observed (and themselves operate via deleterious BMI trajectories).[10, 12, 31] There is, however, some evidence that ACEs are related to poor cardiometabolic health independently of intervening behaviours.[16] ACEs and socioeconomic adversity are proxies of stress and extreme, repetitive exposure may potentially dysregulate the stress response.[32] Early-life adversity has been linked to abnormal cortisol profiles and inflammation, $[33,34]$ both of which are known to be related to, for example, accumulation of visceral fat, impaired fasting glucose, and cardiovascular disease.[35-37]

We observed that socioeconomic adversity was only related to cardiometabolic health status in the overweight/obese group. Socioeconomic adversity tracks across the life course, but because poor health outcomes are observed in children who experience socioeconomic adversity irrespective of their later life socioeconomic environment and conditions, this finding is probably only partly explained by socioeconomic adversity later in adulthood.[38] 
This finding also raises the question of whether the two adversities are working via different pathways, one via and one not via obesity. For example, socioeconomic adversity may be operating through a conventional series of events in which adversity leads to unhealthy behaviours which leads to obesity which leads to poor cardiometabolic health. Conversely, psychosocial adversity may be operating more through biological programming of the stress response in childhood, which leads to poor cardiometabolic health regardless of weight status. This is supported by the fact that we found no association between psychosocial adversity and overweight/obesity in our sample.

A recent survey in a healthcare setting in the UK found that $35 \%$ of adults have experienced two or more ACEs.[39] Our finding that such individuals may have elevated cardiometabolic disease risk is further evidence on the needs to safeguard children and protect them against childhood adversity. Further, to mitigate the effects of childhood adversity, healthcare systems could screen children at risk for ACEs via questionnaires, as is being done in the USA. This could allow for stratification of treatment and intervention programmes to provide the best possible health outcomes, and importantly mitigate the cardiometabolic risks associated with carrying excess adiposity.

The strengths of this study include the utilisation of a large prospective cohort study with follow-up spanning 64 years, most adversities exposures were prospectively collected therefore limiting recall bias, and we were able to re-define weight status groups using DXA \%fat, thereby overcoming a major criticism of the $\mathrm{MHO}$ literature. We only adjusted analyses for assessment age and sex to allow comparison to the Anderson et al [14] paper and because the NSHD has no other measures that we think would have strong causal effects on both our exposures and outcome, and thus meet the requirements to be considered a covariate. Nonetheless, residual confounding is a possibility. Other limitations include small numbers in some sub-groups (e.g., MHNW individuals with 3+ psychosocial adversities), no psychometric evaluation (i.e., reliability and validity) of our adversity scores which included 
maternal-reported and participant-reported retrospective data, and potential underreporting of maltreatment due to its sensitive nature. Retrospective measures of adversity, such as maltreatment, can suffer from low agreement with prospective measures,[40] which might have increased measurement error in our composite adversity scores and resulted in regression dilution bias.[41] Due to sample attrition and eligibility, our analysis sample did not include the full original birth cohort, which may limit generalisability to the population of Great Britain. The meaning and cultural understanding of childhood adversity in the NSHD cohort born in 1946 will be different from contemporary cohorts. Analyses in modern-day cohorts will, therefore, likely be based upon different adversity measures/scores and potentially find different health consequences compared to those reported in the present paper.

\section{CONCLUSION}

Independently of socioeconomic adversity, psychosocial adversity in childhood may be associated with a poor cardiometabolic health profile, in both normal weight and overweight/obese adults. 


\section{REFERENCES}

1. Singh GM, Danaei G, Farzadfar F, Stevens GA, Woodward M, Wormser D, Kaptoge S, Whitlock G, Qiao Q, Lewington S, Di Angelantonio E, Vander Hoorn S, Lawes CM, Ali MK, Mozaffarian D, Ezzati M, Global Burden of Metabolic Risk Factors of Chronic Diseases Collaborating Group, Asia-Pacific Cohort Studies Collaboration, Diabetes Epidemiology Collaborative analysis of Diagnostic criteria in Europe, Emerging Risk Factor Collaboration, Prospective Studies Collaboration. The age-specific quantitative effects of metabolic risk factors on cardiovascular diseases and diabetes: a pooled analysis. PLoS One. 2013;8(7):e65174.

2. Bell JA, Kivimaki M, Hamer M. Metabolically healthy obesity and risk of incident type 2 diabetes: a meta-analysis of prospective cohort studies. Obes Rev. 2014;15(6):504-15.

3. Kramer CK, Zinman B, Retnakaran R. Are metabolically healthy overweight and obesity benign conditions?: A systematic review and meta-analysis. Ann Intern Med. 2013;159(11):758-69.

4. Munoz-Garach A, Cornejo-Pareja I, Tinahones FJ. Does Metabolically Healthy Obesity Exist? Nutrients. 2016;8(6).

5. Johnson W. Body size trajectories and cardio-metabolic resilience to obesity. Nutr Bull. 2018;43(4):456-62.

6. Johnson W. Healthy obesity: time to give up the ghost? Ann Hum Biol. 2018;45(4):297-8.

7. Nedelec R, Jokelainen J, Miettunen J, Ruokonen A, Herzig KH, Mannikko M, Jarvelin MR, Sebert S. Early determinants of metabolically healthy obesity in young adults: study of the Northern Finland Birth Cohort 1966. Int J Obes (Lond). 2018;42(10):170414.

8. Mongraw-Chaffin M, Foster MC, Kalyani RR, Vaidya D, Burke GL, Woodward M, Anderson CA. Obesity Severity and Duration Are Associated With Incident Metabolic Syndrome: Evidence Against Metabolically Healthy Obesity From the Multi-Ethnic Study of Atherosclerosis. J Clin Endocrinol Metab. 2016;101(11):4117-24.

9. Zamrazilova H, Weiss R, Hainer V, Aldhoon-Hainerova I. Cardiometabolic Health in Obese Adolescents Is Related to Length of Obesity Exposure: A Pilot Study. J Clin Endocrinol Metab. 2016;101(8):3088-95.

10. Anda RF, Felitti VJ, Bremner JD, Walker JD, Whitfield C, Perry BD, Dube SR, Giles $\mathrm{WH}$. The enduring effects of abuse and related adverse experiences in childhood. A convergence of evidence from neurobiology and epidemiology. Eur Arch Psychiatry Clin Neurosci. 2006;256(3):174-86. 
11. Galobardes B, Smith GD, Lynch JW. Systematic review of the influence of childhood socioeconomic circumstances on risk for cardiovascular disease in adulthood. Ann Epidemiol. 2006;16(2):91-104.

12. Hughes K, Bellis MA, Hardcastle KA, Sethi D, Butchart A, Mikton C, Jones L, Dunne MP. The effect of multiple adverse childhood experiences on health: a systematic review and meta-analysis. Lancet Public Health. 2017;2(8):e356-e66.

13. Poulton R, Caspi A, Milne BJ, Thomson WM, Taylor A, Sears MR, Moffitt TE. Association between children's experience of socioeconomic disadvantage and adult health: a life-course study. Lancet. 2002;360(9346):1640-5.

14. Anderson EL, Caleyachetty R, Stafford M, Kuh D, Hardy R, Lawlor DA, Fraser A, Howe LD. Prospective associations of psychosocial adversity in childhood with risk factors for cardiovascular disease in adulthood: the MRC National Survey of Health and Development. Int J Equity Health. 2017;16(1):170.

15. Anderson EL, Fraser A, Caleyachetty R, Hardy R, Lawlor DA, Howe LD. Associations of adversity in childhood and risk factors for cardiovascular disease in mid-adulthood. Child Abuse Negl. 2018;76:138-48.

16. Danese A, Moffitt TE, Harrington H, Milne BJ, Polanczyk G, Pariante CM, Poulton R, Caspi A. Adverse childhood experiences and adult risk factors for age-related disease: depression, inflammation, and clustering of metabolic risk markers. Arch Pediatr Adolesc Med. 2009;163(12):1135-43.

17. Wadsworth M, Kuh D, Richards M, Hardy R. Cohort Profile: The 1946 National Birth Cohort (MRC National Survey of Health and Development). Int J Epidemiol. 2006;35(1):49-54.

18. Kuh D, Pierce M, Adams J, Deanfield J, Ekelund U, Friberg P, Ghosh AK, Harwood N, Hughes A, Macfarlane PW, Mishra G, Pellerin D, Wong A, Stephen AM, Richards M, Hardy R, scientific N, data collection t. Cohort profile: updating the cohort profile for the MRC National Survey of Health and Development: a new clinic-based data collection for ageing research. Int J Epidemiol. 2011;40(1):e1-9.

19. Caleyachetty R, Hardy R, Cooper R, Richards M, Howe LD, Anderson E, Kuh D, Stafford M. Modeling Exposure to Multiple Childhood Social Risk Factors and Physical Capability and Common Affective Symptoms in Later Life. J Aging Health. 2018;30(3):386-407.

20. American Diabetes Association. 2. Classification and Diagnosis of Diabetes: Standards of Medical Care in Diabetes-2018. Diabetes Care. 2018;41(Suppl 1):S13S27.

21. Expert Panel on Detection Evaluation Treatment of High Blood Cholesterol in Adults. Executive Summary of The Third Report of The National Cholesterol Education 
Program (NCEP) Expert Panel on Detection, Evaluation, And Treatment of High Blood Cholesterol In Adults (Adult Treatment Panel III). JAMA. 2001;285(19):2486-97.

22. Oh RC, Lanier JB. Management of hypertriglyceridemia. Am Fam Physician. 2007;75(9):1365-71.

23. Prentice AM, Jebb SA. Beyond body mass index. Obes Rev. 2001;2(3):141-7.

24. Heo M, Faith MS, Pietrobelli A, Heymsfield SB. Percentage of body fat cutoffs by sex, age, and race-ethnicity in the US adult population from NHANES 1999-2004. Am J Clin Nutr. 2012;95(3):594-602.

25. Kivimaki M, Smith GD, Juonala M, Ferrie JE, Keltikangas-Jarvinen L, Elovainio M, Pulkki-Raback L, Vahtera J, Leino M, Viikari JS, Raitakari OT. Socioeconomic position in childhood and adult cardiovascular risk factors, vascular structure, and function: cardiovascular risk in young Finns study. Heart. 2006;92(4):474-80.

26. Puolakka E, Pahkala K, Laitinen TT, Magnussen CG, Hutri-Kahonen N, Tossavainen P, Jokinen E, Sabin MA, Laitinen T, Elovainio M, Pulkki-Raback L, Viikari JS, Raitakari OT, Juonala M. Childhood Socioeconomic Status in Predicting Metabolic Syndrome and Glucose Abnormalities in Adulthood: The Cardiovascular Risk in Young Finns Study. Diabetes Care. 2016;39(12):2311-7.

27. Pretty C, O'Leary DD, Cairney J, Wade TJ. Adverse childhood experiences and the cardiovascular health of children: a cross-sectional study. BMC Pediatr. 2013;13:208.

28. Su S, Wang X, Pollock JS, Treiber FA, Xu X, Snieder H, McCall WV, Stefanek M, Harshfield GA. Adverse childhood experiences and blood pressure trajectories from childhood to young adulthood: the Georgia stress and Heart study. Circulation. 2015;131(19):1674-81.

29. Bann D, Johnson W, Li L, Kuh D, Hardy R. Socioeconomic Inequalities in Body Mass Index across Adulthood: Coordinated Analyses of Individual Participant Data from Three British Birth Cohort Studies Initiated in 1946, 1958 and 1970. PLoS Med. 2017;14(1):e1002214.

30. Bann D, Johnson W, Li L, Kuh D, Hardy R. Socioeconomic inequalities in childhood and adolescent body-mass index, weight, and height from 1953 to 2015: an analysis of four longitudinal, observational, British birth cohort studies. Lancet Public Health. 2018;3(4):e194-e203.

31. Hanson MD, Chen E. Socioeconomic status and health behaviors in adolescence: a review of the literature. J Behav Med. 2007;30(3):263-85.

32. Chrousos GP. Stress and disorders of the stress system. Nat Rev Endocrinol. 2009;5(7):374-81.

33. Power C, Thomas C, Li L, Hertzman C. Childhood psychosocial adversity and adult cortisol patterns. Br J Psychiatry. 2012;201(3):199-206. 
34. Rasmussen LJH, Moffitt TE, Eugen-Olsen J, Belsky DW, Danese A, Harrington $H$, Houts RM, Poulton R, Sugden K, Williams B, Caspi A. Cumulative childhood risk is associated with a new measure of chronic inflammation in adulthood. J Child Psychol Psychiatry. 2018.

35. Bjorntorp P. Do stress reactions cause abdominal obesity and comorbidities? Obes Rev. 2001;2(2):73-86.

36. Hackett RA, Kivimaki M, Kumari M, Steptoe A. Diurnal Cortisol Patterns, Future Diabetes, and Impaired Glucose Metabolism in the Whitehall II Cohort Study. J Clin Endocrinol Metab. 2016;101(2):619-25.

37. Haffner SM. The metabolic syndrome: inflammation, diabetes mellitus, and cardiovascular disease. Am J Cardiol. 2006;97(2A):3A-11A.

38. Smith GD, McCarron P, Okasha M, McEwen J. Social circumstances in childhood and cardiovascular disease mortality: prospective observational study of Glasgow University students. J Epidemiol Community Health. 2001;55(5):340-1.

39. ACE evaluation report. Available from: http://www.aces.me.uk/files/2215/3495/0307/REACh Evaluation Report.pdf.

40. Baldwin JR, Reuben A, Newbury JB, Danese A. Agreement Between Prospective and Retrospective Measures of Childhood Maltreatment: A Systematic Review and Metaanalysis. JAMA Psychiatry. 2019;76(6):584-93.

41. Hutcheon JA, Chiolero A, Hanley JA. Random measurement error and regression dilution bias. BMJ. 2010;340:c2289. 
Table 1. Description of study sample, according to weight/health status

\begin{tabular}{|c|c|c|c|c|c|c|}
\hline & & $\begin{array}{l}\text { MHNW } \\
N=194\end{array}$ & $\begin{array}{l}\text { MUNW } \\
N=118\end{array}$ & $\begin{array}{c}\text { MHO } \\
N=257\end{array}$ & $\begin{array}{c}\text { MUO } \\
N=490\end{array}$ & P-value \\
\hline Sex & & & & & & 0.14 \\
\hline Male & $\mathrm{N}(\%)$ & $84(43.3)$ & $51(43.2)$ & $118(45.9)$ & $266(54.3)$ & \\
\hline Female & & $110(56.7)$ & $67(56.8)$ & $139(54.1)$ & $224(45.7)$ & \\
\hline $\begin{array}{l}\text { Psychosocial } \\
\text { adversity score }\end{array}$ & & & & & & 0.24 \\
\hline 0 & $\mathrm{~N}(\%)$ & $96(49.5)$ & $49(41.5)$ & $126(49.0)$ & $216(44.1)$ & \\
\hline 1 & $\mathrm{~N}(\%)$ & $56(28.9)$ & $32(27.1)$ & $67(26.1)$ & $136(27.8)$ & \\
\hline 2 & $\mathrm{~N}(\%)$ & 35 (18.0) & $28(23.7)$ & $51(19.8)$ & 93 (18.9) & \\
\hline$\geq 3$ & $\mathrm{~N}(\%)$ & $7(3.6)$ & $9(7.6)$ & $13(5.1)$ & $45(9.2)$ & \\
\hline $\begin{array}{l}\text { Socioeconomic } \\
\text { adversity score }\end{array}$ & & & & & & 0.004 \\
\hline 0 & $\mathrm{~N}(\%)$ & $57(29.4)$ & $33(28.0)$ & $53(20.6)$ & $81(16.5)$ & \\
\hline 1 & $\mathrm{~N}(\%)$ & $62(32.0)$ & $36(30.5)$ & $94(36.6)$ & $153(31.2)$ & \\
\hline 2 & $\mathrm{~N}(\%)$ & $43(22.2)$ & $30(25.4)$ & $61(23.7)$ & $138(28.2)$ & \\
\hline$\geq 3$ & $\mathrm{~N}(\%)$ & $32(16.5)$ & $19(16.1)$ & $49(10.1)$ & $118(24.1)$ & \\
\hline \multicolumn{7}{|l|}{$\begin{array}{l}\text { Cardiometabolic } \\
\text { health }\end{array}$} \\
\hline \multicolumn{7}{|l|}{ Risk factors } \\
\hline BMI $\left(\mathrm{kg} / \mathrm{m}^{2}\right)$ & Median (IQR) & $23.2(2.3)$ & $23.7(1.6)$ & $27.7(4.1)$ & $29.6(5.4)$ & $<0.001$ \\
\hline \%fat & Mean (SD) & $32.0(7.5)$ & $32.1(6.8)$ & $36.9(7.8)$ & $36.6(7.5)$ & $<0.001$ \\
\hline Systolic $(\mathrm{mmHg})$ & Mean (SD) & $126.2(17.6)$ & $139.8(15.2)$ & $131.5(17.5)$ & $141.8(17.7)$ & $<0.001$ \\
\hline Diastolic $(\mathrm{mmHg})$ & Mean (SD) & $72.4(9.1)$ & $78.8(9.0)$ & $77.0(9.4)$ & $79.9(9.8)$ & $<0.001$ \\
\hline HbA1c (\%) & Median (IQR) & $5.6(0.3)$ & $5.8(0.3)$ & $5.5(0.3)$ & $5.9(0.5)$ & $<0.001$ \\
\hline $\mathrm{HDL}-\mathrm{C}(\mathrm{mmol} / \mathrm{L})$ & Median (IQR) & $1.8(0.5)$ & $1.7(0.5)$ & $1.6(0.5)$ & $1.4(0.4)$ & $<0.001$ \\
\hline Triglycerides (mmol/L) & Median (IQR) & $0.8(0.4)$ & $1.0(0.8)$ & $1.0(0.5)$ & $1.5(1.0)$ & $<0.001$ \\
\hline
\end{tabular}




\begin{tabular}{|c|c|c|c|c|c|c|}
\hline \multicolumn{7}{|l|}{ Complications } \\
\hline Pre-diabetes & $\mathrm{N}(\%)$ & 61 (31.4) & $96(81.4)$ & $59(23.0)$ & $410(83.7)$ & $<0.001$ \\
\hline High blood pressure & $\mathrm{N}(\%)$ & $66(34)$ & $109(92.4)$ & $124(48.3)$ & $446(91.0)$ & $<0.001$ \\
\hline Abnormal HDL-C & $\mathrm{N}(\%)$ & Redacted & $6(5.1)$ & Redacted & $86(17.6)$ & $<0.001$ \\
\hline High Triglycerides & $\mathrm{N}(\%)$ & $11(5.7)$ & $57(48.3)$ & $16(6.2)$ & $331(67.6)$ & $<0.001$ \\
\hline \multicolumn{7}{|l|}{ Medication } \\
\hline Antidiabetic or insulin & $\mathrm{N}(\%)$ & $5(2.6)$ & $8(6.8)$ & $5(2.0)$ & $8(1.6)$ & 0.015 \\
\hline Antihypertensive & $\mathrm{N}(\%)$ & $5(2.6)$ & $14(11.9)$ & $17(6.6)$ & $92(18.8)$ & $<0.001$ \\
\hline Lipid-lowering & $\mathrm{N}(\%)$ & $5(2.6)$ & $38(32.2)$ & $9(3.5)$ & $216(44.1)$ & $<0.001$ \\
\hline \multicolumn{7}{|l|}{ Number of complications } \\
\hline 0 & $\mathrm{~N}(\%)$ & $55(28.4)$ & & $54(21.0)$ & & \\
\hline 1 & $\mathrm{~N}(\%)$ & $139(71.7)$ & & $203(79.0)$ & & \\
\hline 2 & $\mathrm{~N}(\%)$ & & $87(73.7)$ & & $249(50.8)$ & \\
\hline $3-4$ & $\mathrm{~N}(\%)$ & & $31(26.3)$ & & $241(49.2)$ & $<0.001$ \\
\hline
\end{tabular}

Cells with $\mathrm{N}<5$ have been redacted in accordance with the 1946 NSHD data sharing agreement

Metabolically healthy normal weight (MHNW), metabolically unhealthy normal weight (MUNW), metabolically healthy overweight/obese (MHO), and metabolically unhealthy overweight/obese (MUO)

Between-group differences were examined using chi-square for categorical variables and ANOVA for continuous variables (log transformed if not normally distributed). 
Table 2. The relationship between psychosocial and socioeconomic adversity scores

\begin{tabular}{|c|c|c|c|c|c|}
\hline & & \multicolumn{4}{|c|}{ Psychosocial adversity score } \\
\hline & & 0 & 1 & 2 & $\geq 3$ \\
\hline Socioeconomic adversity score & & & & & \\
\hline 0 & $\mathrm{~N}(\%)$ & $114(23.4)$ & $61(21.0)$ & $40(19.3)$ & $9(12.2)$ \\
\hline 1 & $\mathrm{~N}(\%)$ & $173(35.5)$ & $99(34.0)$ & $54(26.1)$ & $19(25.7)$ \\
\hline 2 & $\mathrm{~N}(\%)$ & $114(23.4)$ & $70(24.0)$ & $62(30.0)$ & $26(35.1)$ \\
\hline$\geq 3$ & $\mathrm{~N}(\%)$ & $86(17.7)$ & $61(21.0)$ & $51(24.6)$ & $20(27.0)$ \\
\hline Total & $\mathrm{N}(\%)$ & $487(100)$ & $291(100)$ & $207(100)$ & $74(100)$ \\
\hline
\end{tabular}


Table 3. Separate associations of each childhood psychosocial and socioeconomic adversity scores with metabolic health status or weight status (defined according to $\mathrm{BMI}$ ) in adults aged $60-64$ years $(\mathrm{N}=1,059)$

\begin{tabular}{|c|c|c|c|c|c|c|}
\hline & \multicolumn{3}{|c|}{ Metabolically unhealthy vs healthy } & \multicolumn{3}{|c|}{ Overweight/obese vs normal weight } \\
\hline & $\operatorname{RR}(95 \% \mathrm{Cl})$ & P-value & $\begin{array}{l}P \text {-value } \\
\text { for trend }\end{array}$ & RR $(95 \% \mathrm{Cl})$ & P-value & $\begin{array}{c}\text { P-value for } \\
\text { trend }\end{array}$ \\
\hline \multicolumn{7}{|c|}{$\begin{array}{l}\text { Psychosocial } \\
\text { adversity score }\end{array}$} \\
\hline 0 & 1.00 & & & 1.00 & & \\
\hline 1 & $1.17(0.87,1.57)$ & 0.30 & & $0.99(0.72,1.36)$ & 0.96 & \\
\hline 2 & $1.18(0.85,1.65)$ & 0.31 & & $0.97(0.68,1.39)$ & 0.89 & \\
\hline$\geq 3$ & $2.26(1.31,3.89)$ & 0.03 & 0.009 & $1.54(0.85,2.77)$ & 0.15 & 0.418 \\
\hline \multicolumn{7}{|c|}{$\begin{array}{l}\text { Socioeconomic } \\
\text { adversity score }\end{array}$} \\
\hline 0 & 1.00 & & & 1.00 & & \\
\hline 1 & $1.19(0.85,1.67)$ & 0.32 & & $1.72(1.20,2.46)$ & 0.003 & \\
\hline 2 & $1.62(1.13,2.32)$ & 0.009 & & $1.90(1.30,2.78)$ & 0.001 & \\
\hline$\geq 3$ & $1.69(1.15,2.47)$ & 0.008 & 0.002 & $2.26(1.49,3.42)$ & $<0.001$ & $<0.001$ \\
\hline
\end{tabular}

P-values for trends were obtained by entering the exposures into the models as continuous variables. All models are adjusted for age and sex. 
Table 4. Separate associations of each childhood psychosocial and socioeconomic adversity scores with metabolic health status in normal weight and overweight/obese (defined according to BMI) adults aged 6064 years $(N=1,059)$

\begin{tabular}{|c|c|c|c|c|c|c|}
\hline & \multicolumn{3}{|c|}{ MUNW vs MHNW } & \multicolumn{3}{|c|}{ MUO vs MHO } \\
\hline & $\operatorname{RR}(95 \% \mathrm{Cl})$ & P-value & $\begin{array}{l}\text { P-value } \\
\text { for trend }\end{array}$ & RR (95\% Cl) & P-value & $\begin{array}{c}\text { P-value for } \\
\text { trend }\end{array}$ \\
\hline $\begin{array}{l}\text { Psych } \\
\text { adver }\end{array}$ & & & & & & \\
\hline 0 & 1.00 & & & 1.00 & & \\
\hline 1 & $1.12(0.64,1.95)$ & 0.69 & & $1.22(0.84,1.76)$ & 0.3 & \\
\hline 2 & $1.57(0.86,2.87)$ & 0.15 & & $1.07(0.71,1.61)$ & 0.73 & \\
\hline$\geq 3$ & $2.52(0.88,7.17)$ & 0.08 & 0.05 & $2.01(1.04,3.88)$ & 0.04 & 0.09 \\
\hline $\begin{array}{l}\text { Socio } \\
\text { adver }\end{array}$ & & & & & & \\
\hline 0 & 1.00 & & & 1.00 & & \\
\hline 1 & $1.00(0.55,1.82)$ & 0.99 & & $1.09(0.71,1.68)$ & 0.7 & \\
\hline 2 & $1.21(0.64,2.28)$ & 0.56 & & $1.55(0.98,2.46)$ & 0.06 & \\
\hline$\geq 3$ & $1.03(0.50,2.10)$ & 0.94 & 0.74 & $1.65(1.01,2.67)$ & 0.04 & 0.01 \\
\hline
\end{tabular}

Metabolically healthy normal weight (MHNW), metabolically unhealthy normal weight (MUNW), metabolically healthy overweight/obese (MHO), and metabolically unhealthy overweight/obese (MUO)

P-values for trends were obtained by entering the exposures into the models as continuous variables. All models are adjusted for age and sex. 
Table 5. Mutually-adjusted associations of childhood psychosocial and socioeconomic adversity scores with metabolic health status in normal weight and overweight/obese (defined according to BMI) adults aged $60-64$ years $(N=1,059)$

\begin{tabular}{|c|c|c|c|c|c|c|}
\hline & \multicolumn{3}{|c|}{ MUNW vs MHNW } & \multicolumn{3}{|c|}{ MUO vs MHO } \\
\hline & RR (95\% Cl) & P-value & $\begin{array}{l}\text { P-value } \\
\text { for trend }\end{array}$ & $\operatorname{RR}(95 \% \mathrm{Cl})$ & P-value & $\begin{array}{c}\text { P-value for } \\
\text { trend }\end{array}$ \\
\hline \multicolumn{7}{|c|}{$\begin{array}{l}\text { Psychosocial } \\
\text { adversity score }\end{array}$} \\
\hline 0 & 1.00 & & & 1.00 & & \\
\hline 1 & $1.12(0.64,1.95)$ & 0.69 & & $1.20(0.83,1.74)$ & 0.33 & \\
\hline 2 & $1.56(0.85,2.86)$ & 0.15 & & $1.02(0.68,1.54)$ & 0.92 & \\
\hline$\geq 3$ & $2.49(0.87,7.13)$ & 0.09 & 0.05 & $1.87(0.96,3.61)$ & 0.06 & 0.15 \\
\hline \multicolumn{7}{|c|}{$\begin{array}{l}\text { Socioeconomic } \\
\text { adversity score }\end{array}$} \\
\hline 0 & 1.00 & & & 1.00 & & \\
\hline 1 & $1.00(0.55,1.81)$ & 0.99 & & $1.08(0.70,1.66)$ & 0.74 & \\
\hline 2 & $1.13(0.59,2.14)$ & 0.72 & & $1.50(0.95,2.40)$ & 0.09 & \\
\hline$\geq 3$ & $0.95(0.46,1.96)$ & 0.9 & 0.93 & $1.60(0.98,2.60)$ & 0.06 & 0.02 \\
\hline
\end{tabular}

Metabolically healthy normal weight (MHNW), metabolically unhealthy normal weight (MUNW), metabolically healthy overweight/obese (MHO), and metabolically unhealthy overweight/obese (MUO)

P-values for trends were obtained by entering the exposures into the models as continuous variables. All models are adjusted for age and sex. 
Table 6. Mutually-adjusted associations of childhood psychosocial and socioeconomic adversity scores with metabolic health status in normal weight and overweight/obese (defined according to \%fat) adults aged $60-64$ years $(N=738)$

\begin{tabular}{|c|c|c|c|c|c|c|}
\hline & \multicolumn{3}{|c|}{ MUNW vs MHNW } & \multicolumn{3}{|c|}{ MUO vs MHO } \\
\hline & $\operatorname{RR}(95 \% \mathrm{Cl})$ & P-value & $\begin{array}{l}\text { P-value } \\
\text { for trend }\end{array}$ & RR (95\% Cl) & P-value & $\begin{array}{c}\text { P-value for } \\
\text { trend }\end{array}$ \\
\hline $\begin{array}{l}\text { Psych } \\
\text { adver }\end{array}$ & & & & & & \\
\hline 0 & 1.00 & & & 1.00 & & \\
\hline 1 & $0.81(0.48,1.36)$ & 0.42 & & $1.79(1.10,2.94)$ & 0.02 & \\
\hline 2 & $1.53(0.85,2.78)$ & 0.16 & & $1.03(0.62,1.73)$ & 0.90 & \\
\hline$\geq 3$ & $2.10(0.71,6.20)$ & 0.18 & 0.13 & $1.79(0.82,3.90)$ & 0.15 & 0.2 \\
\hline $\begin{array}{l}\text { Socio } \\
\text { adver }\end{array}$ & & & & & & \\
\hline 0 & 1.00 & & & 1.00 & & \\
\hline 1 & $1.05(0.60,1.84)$ & 0.86 & & $0.93(0.53,1.63)$ & 0.79 & \\
\hline 2 & $0.95(0.52,1.73)$ & 0.86 & & $1.60(0.90,2.99)$ & 0.14 & \\
\hline$\geq 3$ & $1.29(0.64,2.61)$ & 0.47 & 0.63 & $1.22(0.65,2.27)$ & 0.54 & 0.21 \\
\hline
\end{tabular}

Metabolically healthy normal weight (MHNW), metabolically unhealthy normal weight (MUNW), metabolically healthy overweight/obese (MHO), and metabolically unhealthy overweight/obese (MUO)

P-values for trends were obtained by entering the exposures into the models as continuous variables. All models are adjusted for age and sex. 
Supplementary Table 1. Differences between the sample and individuals excluded from analyses due to missing data

\begin{tabular}{|c|c|c|c|c|c|}
\hline & & \multirow{2}{*}{$\begin{array}{l}\text { Included } \\
\mathrm{N}=1,059\end{array}$} & \multicolumn{2}{|l|}{ Excluded } & \multirow[t]{2}{*}{ P-value } \\
\hline & & & $\operatorname{Max} \mathrm{N}=1,170$ & $\mathrm{~N}$ & \\
\hline \multicolumn{6}{|c|}{ Childhood psychosocial adversity exposures } \\
\hline Maltreatment & $\%$ & 4.6 & 6.4 & 937 & 0.08 \\
\hline Low parental concern for child's education & $\%$ & 28.1 & 32.6 & 617 & 0.06 \\
\hline Parental psychiatric history & $\%$ & 2.1 & 2.2 & 1167 & 0.81 \\
\hline Parental divorce & $\%$ & 3.5 & 8.3 & 1167 & $<0.001$ \\
\hline Father affectionless control & $\%$ & 30.5 & 29.2 & 868 & 0.52 \\
\hline Mother affectionless control & $\%$ & 29.4 & 30.6 & 897 & 0.57 \\
\hline Parental death & $\%$ & 3.9 & 9.0 & 1150 & $<0.001$ \\
\hline Maternal separation & $\%$ & 4.2 & 6.2 & 978 & 0.03 \\
\hline Cumulative adversity score & & & & 360 & 0.96 \\
\hline 0 & $\%$ & 46.0 & 44.7 & & \\
\hline 1 & $\%$ & 27.5 & 28.6 & & \\
\hline 2 & $\%$ & 19.6 & 20.0 & & \\
\hline $3+$ & $\%$ & 7.0 & 6.7 & & \\
\hline \multicolumn{6}{|c|}{ Childhood socioeconomic adversity exposures } \\
\hline Low maternal education & $\%$ & 56.5 & 60.9 & 933 & 0.05 \\
\hline Low father social class & $\%$ & 21.9 & 24.9 & 1055 & 0.10 \\
\hline Poorly repaired house & $\%$ & 5.9 & 7.1 & 1092 & 0.26 \\
\hline Poorly cleaned house & $\%$ & 2.1 & 3.4 & 1085 & 0.06 \\
\hline Unclean child & $\%$ & 1.1 & 1.9 & 1091 & 0.14 \\
\hline Unclean childs shoes and clothes & $\%$ & 0.6 & 3.1 & 1091 & $<0.001$ \\
\hline Crowding & $\%$ & 8.4 & 11.7 & 1166 & 0.01 \\
\hline Renting a house from a private landlord & $\%$ & 51.3 & 50.7 & 969 & 0.79 \\
\hline Poor household amenities & $\%$ & 4.4 & 3.3 & 1120 & 0.17 \\
\hline \multicolumn{6}{|l|}{ Socioeconomic adversity score } \\
\hline 0 & $\%$ & 21.2 & 18.4 & 766 & 0.15 \\
\hline 1 & $\%$ & 32.6 & 30.2 & & \\
\hline 2 & $\%$ & 25.7 & 27.6 & & \\
\hline $3+$ & $\%$ & 20.6 & 23.9 & & \\
\hline \multicolumn{6}{|l|}{ Cardiometabolic complications } \\
\hline \multicolumn{6}{|l|}{ Complications } \\
\hline Pre-diabetes & $\%$ & 59.1 & 59.6 & 933 & 0.05 \\
\hline High blood pressure & $\%$ & 70.4 & 72.4 & 1055 & 0.10 \\
\hline Abnormal HDL-C & $\%$ & 9.2 & 11.8 & 1092 & 0.26 \\
\hline High Triglycerides & $\%$ & 39.2 & 38.7 & 1085 & 0.06 \\
\hline Number of complications & & & & 818 & 0.89 \\
\hline 0 & $\%$ & 10.3 & 10.6 & & \\
\hline 1 & $\%$ & 32.3 & 32.4 & & \\
\hline
\end{tabular}




\begin{tabular}{|l|r|r|r|r|r|}
\hline 2 & $\%$ & 31.7 & 32.2 & & \\
\hline 3 & $\%$ & 20.7 & 19.1 & & \\
\hline 4 & $\%$ & 5.0 & 5.8 & & \\
\hline Weight/health status & & & & 806 & 0.81 \\
\hline MHNW & $\%$ & 18.3 & 20.0 & & \\
\hline MUNW & $\%$ & 11.4 & 10.8 & & \\
\hline MHO & $\%$ & 24.3 & 23.1 & & \\
\hline MUO & $\%$ & 46.3 & 46.2 & & \\
\hline
\end{tabular}

Metabolically healthy normal weight (MHNW), metabolically unhealthy normal weight (MUNW), metabolically healthy overweight/obese (MHO), and metabolically unhealthy overweight/obese (MUO)

P-values are from Chi-square tests. 


\begin{tabular}{|c|c|c|c|c|}
\hline & Description & Categories & Age $^{1}$ & Method \\
\hline \multicolumn{5}{|c|}{ Psychosocial adversities } \\
\hline Maltreatment & $\begin{array}{l}\text { Participant asked "As a child do you feel you were } \\
\text { mistreated by your parents in any way?" }\end{array}$ & Yes vs No & 43 years & $\begin{array}{l}\text { Retrospective report by } \\
\text { participants }\end{array}$ \\
\hline $\begin{array}{l}\text { Low parental } \\
\text { concern }\end{array}$ & $\begin{array}{l}\text { Parental concern derived in teacher interviews, in which } \\
\text { teachers were asked "to what extent do this child's parents } \\
\text { show interest in his/her progress at school?" }\end{array}$ & $\begin{array}{l}\text { Little interest vs average to very } \\
\text { interested }\end{array}$ & 13 years & $\begin{array}{l}\text { Teacher questionnaires/school } \\
\text { records and maternal interview }\end{array}$ \\
\hline $\begin{array}{l}\text { Parental } \\
\text { psychiatric history }\end{array}$ & $\begin{array}{l}\text { Mother asked if they or partner had a psychiatric illness } \\
\text { during the } 0-15 \text { yrs of child's life }\end{array}$ & Present vs not present & $0-15$ years & Maternal report \\
\hline Parental divorce & $\begin{array}{l}\text { Experience of parental divorce/separation during the } 0-15 \\
\text { yrs of child's life }\end{array}$ & Divorced vs not divorced & $0-15$ years & Maternal report \\
\hline $\begin{array}{l}\text { Mother } \\
\text { affectionless } \\
\text { control }\end{array}$ & $\begin{array}{l}\text { Parental bonding instrument used to collect retrospective } \\
\text { report of participants perception on their parents' style of } \\
\text { attachment and affection - affectionless control defined: } \\
\text { mothers care score }<27 \text { \& overprotection score }>13.5 .^{2}\end{array}$ & $\begin{array}{l}\text { Affectionless control vs not } \\
\text { affectionless control parenting }\end{array}$ & 43 years & $\begin{array}{l}\text { Retrospective report by } \\
\text { participants }\end{array}$ \\
\hline $\begin{array}{l}\text { Father } \\
\text { affectionless } \\
\text { control }\end{array}$ & $\begin{array}{l}\text { Parental bonding instrument used to collect retrospective } \\
\text { report of participants perception on their parents' style of } \\
\text { attachment and affection - affectionless control defined: } \\
\text { fathers care score }<24 \text { \& overprotection score }>12.5 .^{2}\end{array}$ & $\begin{array}{l}\text { Affectionless control vs not } \\
\text { affectionless control parenting }\end{array}$ & 43 years & $\begin{array}{l}\text { Retrospective report by } \\
\text { participants }\end{array}$ \\
\hline Parental death & $\begin{array}{l}\text { Experience of parental death during the } 0-15 \text { yrs of child's } \\
\text { life }\end{array}$ & $\begin{array}{l}\text { Parental death vs no parental } \\
\text { death }\end{array}$ & $0-15$ years & Reported by parent/ guardian \\
\hline $\begin{array}{l}\text { Maternal } \\
\text { separation }\end{array}$ & $\begin{array}{l}\text { Experience of separation from the mother during the } 0-6 \text { yrs } \\
\text { of child's life }\end{array}$ & $\begin{array}{l}\text { Separation (permanent, regular, } \\
\text { or } \geq 9 \text { weeks) vs no separation } \\
\text { (<3.5 days) }\end{array}$ & $0-6$ years & Maternal reports \\
\hline \multicolumn{5}{|c|}{ Socioeconomic adversities } \\
\hline $\begin{array}{l}\text { Low father social } \\
\text { class }\end{array}$ & $\begin{array}{l}\text { Fathers occupation according to the UK Registrar General's } \\
\text { Classification }\end{array}$ & $\begin{array}{l}\text { Semiskilled and unskilled } \\
\text { manual vs professional, } \\
\text { intermediate, skilled, nonmanual, } \\
\text { and skilled manual }\end{array}$ & $\begin{array}{l}4 \text { years } \\
\text { (or } 7 / 11 \text { if } \\
\text { missing) }\end{array}$ & Maternal report of occupation \\
\hline $\begin{array}{l}\text { Renting a house } \\
\text { from a private } \\
\text { landlord }\end{array}$ & Housing tenure & $\begin{array}{l}\text { Private landlord owned home vs } \\
\text { nonprivate landlord owned home } \\
\text { (council, charitable trust, and } \\
\text { home owner) }\end{array}$ & $\begin{array}{l}2 \text { years } \\
\text { (or } 11 / 15 \text { years if } \\
\text { missing) }\end{array}$ & Maternal/health visitor reports \\
\hline $\begin{array}{l}\text { Poor household } \\
\text { amenities }\end{array}$ & $\begin{array}{l}\text { Household amenities: sole of use of a kitchen, sole use of a } \\
\text { bathroom, running hot water }\end{array}$ & $\begin{array}{l}\text { Lacks } 3 \text { amenities vs } 0-2 \\
\text { amenities }\end{array}$ & $\begin{array}{l}2 \text { years } \\
\text { (or } 11 / 15 \text { years if } \\
\text { missing) }\end{array}$ & Maternal reports \\
\hline $\begin{array}{l}\text { Household } \\
\text { overcrowding }\end{array}$ & Number of people living in rooms & $>2$ people per room vs $<2$ & $\begin{array}{l}2 \text { years } \\
\text { (or } 4 / 6 / 8 / 11 / 15 \\
\text { years if missing) }\end{array}$ & $\begin{array}{l}\text { Maternal reports of who lives in } \\
\text { house and number of rooms }\end{array}$ \\
\hline $\begin{array}{l}\text { Poorly repaired } \\
\text { house }\end{array}$ & $\begin{array}{l}\text { Health visitor's assessment of the state of repair of the } \\
\text { house in comparison to others they had visited }\end{array}$ & Bad vs average to very good & 4 years & Health visitor report \\
\hline
\end{tabular}




\begin{tabular}{|c|c|c|c|c|}
\hline & & & $\begin{array}{l}\text { (or } 6 / 11 \text { years if } \\
\text { missing) }\end{array}$ & \\
\hline Unclean child & $\begin{array}{l}\text { Health visitor's assessment of the cleanliness of the subject } \\
\text { in comparison with other children visited }\end{array}$ & $\begin{array}{l}\text { Least clean vs average to most } \\
\text { clean }\end{array}$ & $\begin{array}{l}4 \text { years } \\
\text { (or 6/9/11 years if } \\
\text { missing) }\end{array}$ & Health visitor report \\
\hline $\begin{array}{l}\text { Poorly cleaned } \\
\text { house }\end{array}$ & $\begin{array}{l}\text { Health visitor's assessment of the cleanliness of subject } \\
\text { house compared with others }\end{array}$ & $\begin{array}{l}\text { Least clean vs average to most } \\
\text { clean }\end{array}$ & $\begin{array}{l}4 \text { years } \\
\text { (or 6/9/11 years if } \\
\text { missing) }\end{array}$ & Health visitor report \\
\hline $\begin{array}{l}\text { Poor state of } \\
\text { child's clothes and } \\
\text { shoes }\end{array}$ & $\begin{array}{l}\text { Health visitor's assessment compared with other children } \\
\text { under their care }\end{array}$ & Unsatisfactory vs satisfactory & $\begin{array}{l}4 \text { years } \\
\text { (or 6/9/11 years if } \\
\text { missing) }\end{array}$ & Health visitor report \\
\hline
\end{tabular}

${ }^{1}$ We used adversity measures from the earliest possible visit. If an individual was missing data, we used their measure from the next visit. For example, "4 years (or 7/11 years if missing)" means we used data from the age 4 years visit. If this was missing, we used data from the age 7 years visit. And if this was missing, we used data from the age 11 years visit.

${ }^{2}$ Caleyachetty R, Hardy R, Cooper R, Richards M, Howe LD, Anderson E, Kuh D, Stafford M. Modeling Exposure to Multiple Childhood Social Risk Factors and Physical Capability and Common Affective Symptoms in Later Life. J Aging Health. 2018;30(3):386-407 


\begin{tabular}{|c|c|c|c|c|c|c|}
\hline & & $\begin{array}{c}\text { MHNW } \\
194\end{array}$ & $\begin{array}{c}\text { MUNW } \\
118\end{array}$ & $\begin{array}{c}\text { MHO } \\
257\end{array}$ & $\begin{array}{c}\text { MUO } \\
490\end{array}$ & P Values \\
\hline \multicolumn{7}{|c|}{ Childhood psychosocial adversity exposures } \\
\hline Maltreatment & $\mathrm{N}(\%)$ & $9(4.6)$ & Redacted & $12(4.7)$ & $24(4.9)$ & Redacted \\
\hline Parental neglect (interest in education) & $\mathrm{N}(\%)$ & $13(6.7)$ & $16(13.6)$ & $23(8.9)$ & $62(12.7)$ & 0.07 \\
\hline Parental mental illness & $\mathrm{N}(\%)$ & Redacted & Redacted & Redacted & $14(2.9)$ & 0.4 \\
\hline Parental divorce & $\mathrm{N}(\%)$ & Redacted & Redacted & $9(3.5)$ & $25(5.1)$ & 0.02 \\
\hline Low paternal bonding & $\mathrm{N}(\%)$ & $57(29.4)$ & $35(29.7)$ & $72(28.0)$ & $159(32.4)$ & 0.62 \\
\hline Low maternal bonding & $\mathrm{N}(\%)$ & $54(27.8)$ & $45(38.1)$ & $67(26.1)$ & $145(29.6)$ & 0.11 \\
\hline Parental death & $\mathrm{N}(\%)$ & Redacted & $6(5.1)$ & $13(5.1)$ & $18(3.7)$ & Redacted \\
\hline Maternal separation & $\mathrm{N}(\%)$ & $7(3.6)$ & $7(5.9)$ & $11(4.3)$ & $19(3.9)$ & 0.76 \\
\hline \multicolumn{7}{|c|}{ Childhood socioeconomic adversity exposures } \\
\hline Low maternal education & $\mathrm{N}(\%)$ & $85(43.8)$ & $64(54.2)$ & $141(54.9)$ & $308(62.9)$ & $<0.001$ \\
\hline Low paternal social class & $\mathrm{N}(\%)$ & $26(13.4)$ & $29(24.6)$ & $54(21.0)$ & $123(25.1)$ & 0.008 \\
\hline Bad state of repair of the house & $\mathrm{N}(\%)$ & $13(6.7)$ & Redacted & $12(4.7)$ & $33(6.7)$ & Redacted \\
\hline Unclean house/unsanitary living conditions & $\mathrm{N}(\%)$ & Redacted & Redacted & Redacted & $18(3.7)$ & 0.004 \\
\hline Unclean child & $\mathrm{N}(\%)$ & Redacted & Redacted & Redacted & $9(1.8)$ & 0.13 \\
\hline Unclean clothes and shoes & $\mathrm{N}(\%)$ & Redacted & Redacted & Redacted & $5(1.0)$ & 0.27 \\
\hline Crowded living conditions & $\mathrm{N}(\%)$ & $15(7.7)$ & $9(7.6)$ & $24(9.3)$ & $41(8.4)$ & 0.92 \\
\hline Renting a house from a private landlord & $\mathrm{N}(\%)$ & $103(53.1)$ & $50(42.4)$ & $127(49.4)$ & $263(53.7)$ & 0.14 \\
\hline Lack of amenities & $\mathrm{N}(\%)$ & $6(3.1)$ & Redacted & $15(5.8)$ & $23(4.7)$ & Redacted \\
\hline
\end{tabular}

Cells with $\mathrm{N}<5$ have been redacted in accordance with the 1946 NSHD data sharing agreement

Metabolically healthy normal weight (MHNW), metabolically unhealthy normal weight (MUNW), metabolically healthy overweight/obese (MHO), and metabolically unhealthy overweight/obese (MUO) 
Supplementary Table 4. Multiple imputation results - mutually-adjusted associations of childhood psychosocial and socioeconomic adversity scores with metabolic health status in normal weight and overweight/obese (defined according to BMI) adults aged 60-64 years $(\mathrm{N}=1,865)$

\begin{tabular}{|l|r|r|r|r|r|r|}
\hline & \multicolumn{2}{|c|}{ MUNW vs MHNW } & \multicolumn{2}{c|}{ MUO vs MHO } \\
\hline & RR (95\% CI) & P-value & $\begin{array}{c}\text { P-value } \\
\text { for trend }\end{array}$ & RR (95\% CI) & P-value & $\begin{array}{c}\text { P-value for } \\
\text { trend }\end{array}$ \\
\hline $\begin{array}{l}\text { Psychosocial } \\
\text { adversity score }\end{array}$ & & & & & & \\
\hline 0 & $1.16(0.73,1.84)$ & 0.528 & & $1.09(0.81,1.47)$ & 0.581 & \\
\hline 1 & $1.21(0.72,2.04)$ & 0.466 & & $1.15(0.72,1.86)$ & 0.535 & \\
\hline 2 & $1.90(0.91,4.00)$ & 0.089 & 0.119 & $1.70(0.93,3.13)$ & 0.082 & 0.144 \\
\hline$\geq 3$ & & & & & & \\
\hline $\begin{array}{l}\text { Socioeconomic } \\
\text { adversity score }\end{array}$ & $1.12(0.68,1.83)$ & 0.662 & & $1.20(0.80,1.79)$ & 0.367 & \\
\hline 0 & $1.25(0.74,2.10)$ & 0.407 & & $1.49(1.01,2.19)$ & 0.042 & \\
\hline 1 & $1.18(0.70,2.00)$ & 0.539 & 0.432 & $1.61(1.06,2.43)$ & 0.025 & 0.008 \\
\hline 2 & & & & & & \\
\hline$\geq 3$ & & & & & & \\
\hline
\end{tabular}

Metabolically healthy normal weight (MHNW), metabolically unhealthy normal weight (MUNW), metabolically healthy overweight/obese (MHO), and metabolically unhealthy overweight/obese (MUO)

P-values for trends were obtained by entering the exposures into the models as continuous variables. All models are adjusted for age and sex. 